\title{
AMOT Gene
}

National Cancer Institute

\section{Source}

National Cancer Institute. AMOT Gene. NCI Thesaurus. Code C98143.

This gene plays a role in tight junction formation. 